\title{
Comparison the Effectiveness of Breastfeeding, Oral 25\% Dextrose, Kangaroo-Mother Care Method, and EMLA Cream on Pain Score Level Following Heal Pick Sampling in Newborns: a randomized clinical trial
}

\author{
Soroosh Soltani ${ }^{1}$, Dariush Zohoori ${ }^{2}$, Mojtaba Adineh ${ }^{3}$
}

${ }^{1}$ Medical Student, Student Research Committee, International Branch, Shiraz University of Medical Sciences, Shiraz, Iran

${ }^{2}$ M.D., Pediatrician, Assistant Professor, Department of Pediatrics and Neonatology, International Branch, Shiraz University of Medical Sciences, Shiraz, Iran

${ }^{3}$ M.D., Fellowship of Neonatalogy, Department of Pediatrics and Neonatology, Mashhad University of Medical Sciences, Mashhad, Iran

Type of article: Original

\begin{abstract}
Background: Today, it is considered that infants can feel pain, and it can have several adverse effects on their development. Although different interventions, such as skin-to-skin contact (kangaroo mother care method), glucose solutions, breastfeeding, and local anesthetic agents, have been evaluated to reduce infants' pain, there is no clinical trial available to identify the best method.

Objective: The aim of this study was to compare the efficacy of four methods of relieving infants' pain, i.e., breastfeeding, oral $25 \%$ dextrose, kangaroo mother care method (KMCM), and EMLA cream based on a pain score level following heal-prick sampling in term newborns.

Methods: In this double-blind, controlled, randomized clinical trial, full term, and healthy infants in Shahid Motahhari Hospital, Marvdasht, Shiraz Province, Iran were studied. Infants were randomly allocated to four groups of interventions, i.e., A: breast milk feeding $(\mathrm{n}=42)$, B: oral $25 \%$ dextrose $(\mathrm{n}=40), \mathrm{C}: \mathrm{KMCM}(\mathrm{n}=38)$, and D: KMCM ointment $(n=40)$. All interventions were applied 15 minutes before heel-prick sampling. To evaluate the pain level in infants, the Neonatal Infant Pain Scale (NIPS) questionnaire was used. The data were analyzed with SPSS version 16 by ANOVA and the chi-squared tests.

Results: One hundred and sixty-one infants (93 males, 68 females) with an age range of 3 to 5 days were studied. There was no significant difference between the groups in terms of gender $(\mathrm{p}=0.113)$, weight $(\mathrm{p}=0.059)$, and baseline pain score level $(\mathrm{p}=0.904)$. The breastfeeding method showed the lowest pain score in comparison to the other interventions $(\mathrm{A}=5.52 \pm 2.22, \mathrm{~B}=6.45 \pm 1.88, \mathrm{C}=6.84 \pm 1.96, \mathrm{D}=7.37 \pm 1.95 ; \mathrm{p}=0.001)$ after the heel-prick sampling.

Conclusion: It seems that, among the four methods of interventions in this study, the most effective method of lowering perceived pain in infants undergoing painful procedures was proven to be breastfeeding.

Trial Registration: This study is registered in the Iranian Registry of Clinical Trials with the registration number of IRCT20151201253256N1.

Funding: This research was supported financially by the Research Council of the International Campus of Shiraz University of Medical Sciences.

Keywords: Kangaroo-Mother Care Methods, Breastfeeding, Dextrose, EMLA, Infant, Pain, Pain Management, Neonatal Infant Pain Scale
\end{abstract}

\section{Corresponding author:}

Assistant Professor Dr. Dariush Zohoori, Department of Pediatrics and Neonatology, International Branch, Shiraz University of Medical Sciences, Shiraz, Iran.

Tel: +98.7143333278, Fax: +98.7143333278, Email: dzohoori@gmail.com

Received: October 11, 2015, Accepted: January 17, 2016, Published: May 2018

iThenticate screening: January 30, 2016, English editing: March 06, 2016, Quality control: September 26, 2016

(C) 2018 The Authors. This is an open access article under the terms of the Creative Commons Attribution-NonCommercialNoDerivs License, which permits use and distribution in any medium, provided the original work is properly cited, the use is non-commercial and no modifications or adaptations are made. 


\section{Introduction}

Pain is an undesirable sensation usually accompanied by tissue damage, which is now perceived to be felt even by infants $(1,2)$. Prolonged, repetitive pain endured during infancy can have semi-permanent effects on the way the autonomic nervous system performs, and, also, it can cause disturbances in nervous system development, attention level, learning abilities, and behavioral patterns $(3,4)$. Pain expression in infants is different from older children and adults, and it may present with certain behavioral and physiological reactions, including facial changes, such as eyebrows rising, eyes squeezing, nasolabial folds creasing, and physiological reactions, such as crying and tachycardia. Using these features, many techniques and tools have been utilized to quantify pain in infants (5-7). Many studies have been performed to find the best way to reduce pain in infants, which mainly include skin-to-skin contact (kangaroo mother care method (KMCM)); glucose solutions, such as dextrose; breastfeeding; and local anesthetic agents, such as EMLA; however, no study is available to compare these four methods in one setting (5, 8). The main disadvantage of KMCM is that it is utilized mainly for premature and low-birthweight infants, and just a limited number of studies have been performed on full-term and healthy infants (9-12). Sugary solutions, such as dextrose, glucose, or sucrose solutions bind to the sweet taste receptors and cause a surge of endorphins, which leads to lowering the sensation of pain and elevating the pain threshold level; however, its efficacy for analgesia has been reported differently in recent studies (13-16). It assumes that breast milk feeding, as another method for analgesia, reduces the pain sensation through three different mechanisms, i.e., endorphin release due to sweet taste, skin contact and cradling during breastfeeding, and the sucking reflex (17-22). Also, the administration of local anesthetic agents, such as EMLA cream (lidocaine 2.5\% and prilocaine 2.5\%), has been proven to be effective in lowering the pain sensation $(17,23)$, but, in some studies, its safety and power of effectiveness has not been approved yet (24-27). To date, there is no clinical trial available to clarify the best method of analgesia in newborns with a comparison of these four interventions in one setting. So, it can be concluded that a study is required to compare different methods and reach a conclusion concerning the best method to reduce the pain sensation in fullterm, healthy newborns. The aim of this study was to compare the efficacy of four methods, i.e., breastfeeding, oral $25 \%$ dextrose, KMCM, and EMLA cream on pain score levels following heal prick sampling in full-term newborns.

\section{Material and Methods}

\subsection{Study Design}

This was a double-blinded, randomized, clinical trial conducted in full-term, healthy newborns at Shahid Motahhari Hospital, Marvdasht, Shiraz Province, Iran, from March to December 2015.

\subsection{Study Population}

The inclusion criteria were infants with gestational age of 37 to 42 weeks, who had an Apgar score of +9 at birth, birth weight of 2500-4000 grams, and ages between 3 and 5 days who were candidates for heel-prick sampling. The exclusion criteria were infants who had mothers with a history of gestational hypertension or diabetes, those being fed with infant formula, or those who had a nil per os (NPO) diet condition, and those who were found to have a remarkable, unusual finding in their physical examinations.

\subsection{Sample Determination}

According to previous studies that showed a mean pain score of 6 in the dextrose intervention group, and 8 scores in skin-to-skin contact, breast milk, and EMLA intervention groups, with a standard deviation of 3, we estimated a sample size of 40 newborns in each group using $\alpha$ level of significance at 0.05 with a power of $80 \%$ and difference score of 2 .

\subsection{Blinding and allocation}

The infants were allocated randomly using envelopes that contained a pain-management method among four groups, i.e., A, B, C, and D. The double-blinded method was set up for this study. The nurse in charge of the heel-prick sampling was not aware of the pre-sampling pain management method. Also, pain score levels were mentioned by one certain medical student who was not aware of the pain-management method in each infant according to the Neonatal Infant Pain Scale parameters.

\subsection{Interventions}

Infants were allocated randomly to four groups of interventions, i.e., A: breast milk feeding $(n=42)$, B: oral $25 \%$ dextrose $(n=40), C:$ KMCM ( $n=38)$, and D: KMCM ointment ( $n=40)$. All interventions (A: breast milk feeding; B: 2 milliliters of oral $25 \%$ dextrose; C: KMCM; and D: EMLA ointment) were applied 15 minutes before heel-prick 
sampling (Figure 1). Then, all infants were subjected to heel-prick sampling, done by one nurse in the pediatric ward in a single work shift using 23 Gauge Scalp needle (Supa Company, Iran).

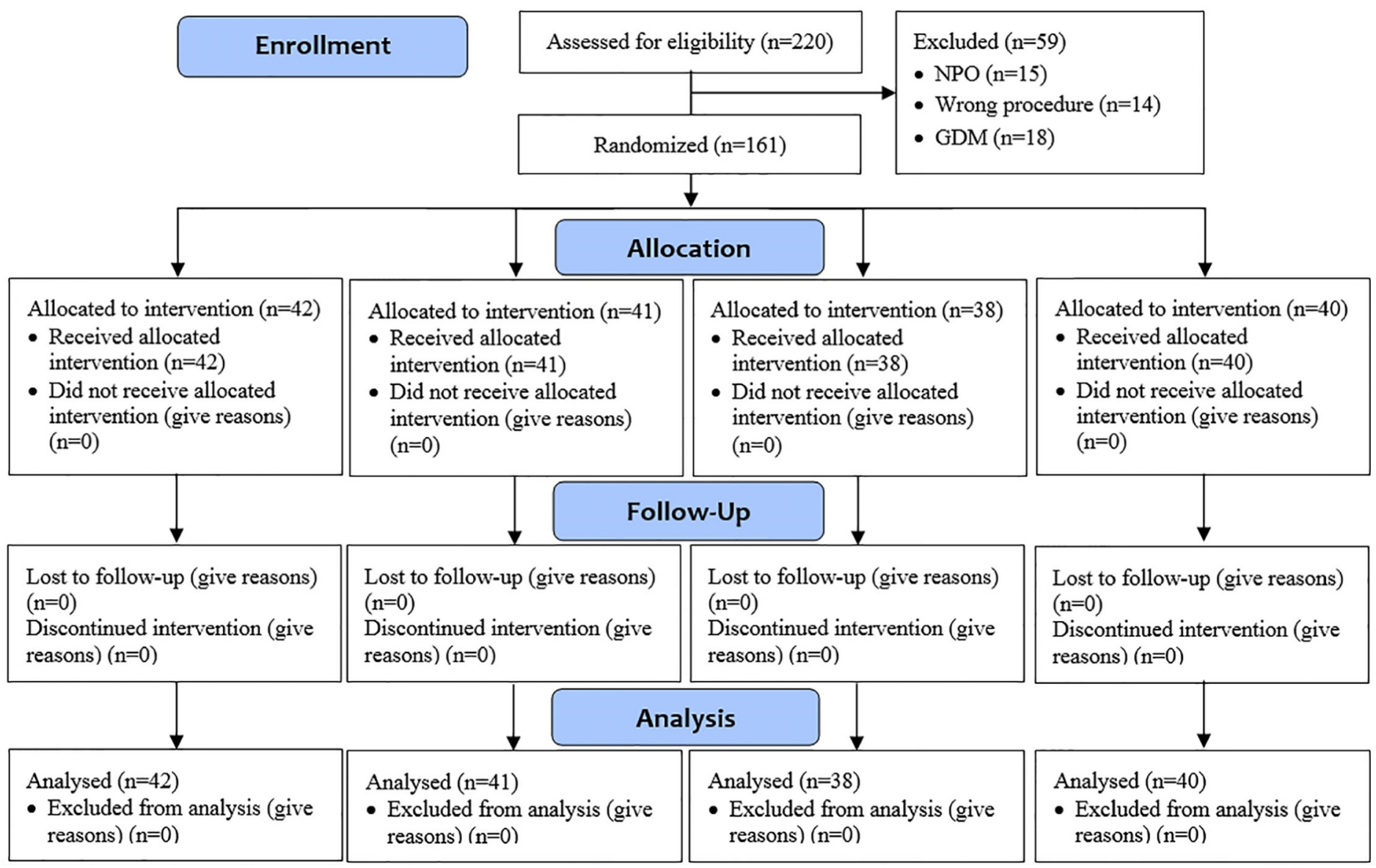

Figure1. Consort 2010 Flow Diagram of the study

\subsection{Studied Variables}

Before the interventions, the subjects' gender, weight, and baseline pain level score before the interventions were documented, and, immediately after applying the various intervention methods and sampling, the pain level score and NIPS questionnaire parameters were documented.

\subsection{Neonatal Infant Pain Scale}

To evaluate the perceived pain level in infants, the Neonatal Infant Pain Scale (NIPS) (7) questionnaire was used. This method is used in premature and full-term infants for up to six weeks after birth and includes parameters, such as crying, limb movement, facial expressions, respiratory pattern, heart rate, $\mathrm{O} 2$ saturation, and state of arousal. The details of this system are as follows: Crying (0: no cry, 1: whimper, 2: vigorous), facial expression (0: relaxed, 1: grimace), breathing pattern (0: relaxed, 1: change in breathing pattern), arms and legs each (0: relaxed, 1: flexed/extended), and state of arousal (0: sleeping/awake, 1: fussy), and the total pain score ranges between 0-10. Validity and reliability of this questionnaire have been approved by Suraseranivongse et al. (28), and its Farsilanguage version had been approved earlier (29).

\subsection{Research Ethics}

This study was approved by the Ethics Committee of Shiraz University of Medical Sciences (Code: IR.SUMS.REC.1394.156), and all of the subjects' parents were informed regarding the details of the study and signed a consent form.

\subsection{Statistical Analysis}

The statistical analysis was done using SPSS software, version 16 (SPSS Inc., Chicago, IL, USA). Baseline demographics and NIPS questionnaire parameters were compared among study groups using ANOVA and the chi- 
http://www.ephysician.ir

squared test and the Fisher exact test, as deemed appropriate. The confidence interval was set at $95 \%$, and statistical significance was set at $\mathrm{p}=0.05$.

\section{Results}

\subsection{Baseline Characteristics}

This study was conducted on 161 subjects (93 males, 68 females) with an age range of 3 to 5 days. The subjects' mean weight was $3.07 \pm 0.63$ kilograms. Each of the four groups were divided as follows: A: breast milk feeding $(n=42)$, B: oral $25 \%$ dextrose $(n=40), C:$ KMCM $(n=38)$, and D: KMCM ointment ( $n=40)$. The groups had no statistically significant difference regarding weight, gender, and the baseline total pain score (Table 1).

\subsection{Total Pain Score}

After the interventions, 14 of the subjects (8.7\%) experienced mild pain (NIPS score: $0-3$ ), 53 of the subjects (32.9\%) experienced moderate pain (NIPS score: 4-6), and 94 of the subjects (58.4\%) experienced severe pain (NIPS score: 7-10). The average pain score was 6.53 \pm 2.11 (moderate pain). The average pain score in group A (breast milk feeding) was $5.52 \pm 2.22$ and was significantly lower than the rest of the groups ( $p=0.00)($ Table 2$)$. Group B (25\% dextrose) was in second place with an average pain score of $6.45 \pm 1.88$ (Table 2). The posthoc test showed that there were statistically significant differences between groups A and D $(\mathrm{p}=0.00)$ and between groups $\mathrm{A}$ and $\mathrm{C}(\mathrm{p}=0.021)$, and they resulted in a significant difference between all four groups. Moreover, through the chisquared analysis, it was found that there was a statistically significant correlation between the type of intervention and the total pain score categories $(\mathrm{p}=0.005)$; group $\mathrm{A}$ had the least frequency of severe pain and the largesst number of mild pain scores (Table 3 ).

\subsection{NIPS Questionnaire Parameters}

There was no significant difference among the four groups regarding oxygen $(\mathrm{O} 2)$ saturation levels, heart rate, and state of arousal (Table 2). However, there was a statistically significant difference between the groups regarding breathing pattern, crying, arm and leg flexion/extension, and facial expression (Table 2). The least amount of pain scores according to crying, arm and leg flexion/extension, and facial expression were attributed to group A, while, according to breathing pattern, it was attributed to group B (Table 2). Moreover, according to the chi-squared analysis results, by converting quantitative data to qualitative data, there was a statistically significant correlation between the type of intervention and the total pain score regarding crying, arm and leg flexion/extension, facial expression, breathing pattern, and heart rate (Table 3).

Table 1. Baseline information of the subjects divided into groups

\begin{tabular}{|l|l|l|l|l|l|l|}
\hline Variables & & $\begin{array}{l}\text { Breast Milk } \\
(\mathrm{n}=42)\end{array}$ & $\begin{array}{l}\text { EMLA Ointment } \\
(\mathrm{n}=41)\end{array}$ & $\begin{array}{l}\text { Skin-contact } \\
(\mathrm{n}=38)\end{array}$ & $\begin{array}{l}25 \% \text { Dextrose } \\
(\mathrm{n}=40)\end{array}$ & $\mathrm{p}$-value \\
\hline Gender & Male, $\mathrm{n}$ & 18 & 24 & 26 & 25 & 0.113 \\
\cline { 2 - 7 } & Female, $\mathrm{n}$ & 24 & 17 & 12 & 15 & 0.059 \\
\hline Weight & $\begin{array}{l}\mathrm{kg}, \text { Mean } \pm \\
\text { SD }\end{array}$ & $2.88 \pm 0.95$ & $3.04 \pm 0.45$ & $3.26 \pm 0.42$ & $3.11 \pm 0.46$ & 0.904 \\
\hline $\begin{array}{l}\text { Pain Score } \\
\text { level }\end{array}$ & Mean \pm SD & $0.19 \pm 0.02$ & $0.19 \pm 0.01$ & $0.20 \pm 0.06$ & $0.18 \pm 0.08$ & 0.004 \\
\hline
\end{tabular}

Table 2. Comparison of the NIPS variables and the total pain score for four intervention methods (Quantitative)

\begin{tabular}{|l|l|l|l|l|l|}
\hline Variables, Mean \pm SD & $\begin{array}{l}\text { Breast Milk } \\
(\mathrm{n}=42)\end{array}$ & $\begin{array}{l}\text { EMLA Ointment } \\
(\mathrm{n}=41)\end{array}$ & $\begin{array}{l}\text { Skin-contact } \\
(\mathrm{n}=38)\end{array}$ & $\begin{array}{l}25 \% \text { Dextrose } \\
(\mathrm{n}=40)\end{array}$ & p-value \\
\hline Facial expression & $0.67 \pm 0.47$ & $0.93 \pm 0.26$ & $0.76 \pm 0.43$ & $0.70 \pm 0.46$ & $0.02^{*}$ \\
\hline Crying & $1.14 \pm 0.60$ & $1.59 \pm 0.59$ & $1.26 \pm 0.64$ & $1.20 \pm 0.60$ & $0.00^{*}$ \\
\hline Breathing pattern & $0.69 \pm 0.46$ & $0.90 \pm 0.30$ & $0.84 \pm 0.37$ & $0.65 \pm 0.48$ & $0.01^{*}$ \\
\hline Movements of Arms & $0.64 \pm 0.48$ & $0.90 \pm 0.30$ & $0.87 \pm 0.34$ & $0.82 \pm 0.38$ & $0.01^{*}$ \\
\hline Movements of Legs & $0.69 \pm 0.46$ & $0.88 \pm 0.33$ & $0.84 \pm 0.37$ & $0.95 \pm 0.22$ & $0.01^{*}$ \\
\hline State of arousal & $0.69 \pm 0.46$ & $0.85 \pm 0.35$ & $0.89 \pm 0.31$ & $0.87 \pm 0.33$ & 0.57 \\
\hline Heart rate & $1.05 \pm 0.49$ & $1.34 \pm 0.57$ & $1.24 \pm 0.82$ & $1.20 \pm 0.68$ & 0.23 \\
\hline Oxygen saturation & $0.0 \pm 0.0$ & $0.0 \pm 0.0$ & $0.0 \pm 0.0$ & $0.0 \pm 0.0$ & - \\
\hline Pain Score level & $5.52 \pm 2.22$ & $7.37 \pm 1.95$ & $6.84 \pm 1.96$ & $6.45 \pm 1.88$ & $0.00^{*}$ \\
\hline
\end{tabular}


Table 3. Comparison of NIPS variables and total pain score among four intervention methods (Qualitative)

\begin{tabular}{|c|c|c|c|c|c|c|}
\hline \multicolumn{2}{|l|}{ Variable } & \multirow{2}{*}{$\begin{array}{l}\begin{array}{l}\text { Breast Milk } \\
(\mathrm{n}=42)\end{array} \\
7\end{array}$} & \multirow{2}{*}{$\begin{array}{l}\begin{array}{l}\text { Ointment } \\
(\mathrm{n}=41)\end{array} \\
3 \\
\end{array}$} & \multirow{2}{*}{$\begin{array}{l}\begin{array}{l}\text { Skin-contact } \\
(\mathrm{n}=38)\end{array} \\
2\end{array}$} & \multirow{2}{*}{\begin{tabular}{|l|}
$\begin{array}{l}\text { Dextrose } \\
(\mathrm{n}=40)\end{array}$ \\
2
\end{tabular}} & \multirow{2}{*}{$\begin{array}{l}\text { p-value } \\
0.00^{*}\end{array}$} \\
\hline \multirow{3}{*}{$\begin{array}{l}\text { Pain score } \\
\text { category }\end{array}$} & Mild (0-3) & & & & & \\
\hline & Moderate (4-6) & 18 & 5 & 13 & 17 & \\
\hline & Severe $(7-10)$ & 17 & 33 & 23 & 21 & \\
\hline \multirow{2}{*}{$\begin{array}{l}\text { Facial } \\
\text { Expression }\end{array}$} & Relaxed & 14 & 3 & 9 & 12 & \multirow[t]{2}{*}{$0.02 *$} \\
\hline & Grimace & 28 & 38 & 29 & 28 & \\
\hline \multirow[t]{3}{*}{ Crying } & No cry & 5 & 2 & 4 & 4 & \multirow[t]{3}{*}{$0.021 *$} \\
\hline & Whimper & 26 & 13 & 20 & 24 & \\
\hline & Vigorous & 11 & 26 & 14 & 12 & \\
\hline \multirow{2}{*}{$\begin{array}{l}\text { Breathing } \\
\text { pattern }\end{array}$} & Relaxed & 13 & 4 & 6 & 14 & \multirow[t]{2}{*}{$0.019 *$} \\
\hline & $\begin{array}{l}\text { Change in breathing } \\
\text { pattern }\end{array}$ & 29 & 37 & 32 & 26 & \\
\hline \multirow{2}{*}{$\begin{array}{l}\text { Movement of } \\
\text { Arms }\end{array}$} & Relaxed & 15 & 4 & 5 & 7 & \multirow[t]{2}{*}{$0.013 *$} \\
\hline & Flexed/extended & 27 & 37 & 33 & 33 & \\
\hline \multirow{2}{*}{$\begin{array}{l}\text { Movement of } \\
\text { Legs }\end{array}$} & Relaxed & 13 & 5 & 6 & 2 & \multirow[t]{2}{*}{$0.011 *$} \\
\hline & Flexed/extended & 29 & 36 & 32 & 38 & \\
\hline \multirow{2}{*}{$\begin{array}{l}\text { State of } \\
\text { arousal }\end{array}$} & Sleeping/awake & 13 & 6 & 4 & 5 & \multirow[t]{2}{*}{0.057} \\
\hline & Fussy & 29 & 35 & 34 & 35 & \\
\hline \multirow[t]{3}{*}{ Heart rate } & Within $10 \%$ of baseline & 4 & 2 & 9 & 6 & \multirow[t]{3}{*}{$0.001 *$} \\
\hline & $11-20 \%$ of baseline & 32 & 23 & 11 & 20 & \\
\hline & $>20 \%$ of baseline & 6 & 16 & 18 & 14 & \\
\hline \multirow[t]{2}{*}{$\begin{array}{l}\text { Oxygen } \\
\text { saturation }\end{array}$} & $\begin{array}{l}\text { No additional need to } \\
\text { maintain oxygen }\end{array}$ & 42 & 41 & 38 & 40 & \multirow[t]{2}{*}{-} \\
\hline & $\begin{array}{l}\text { Additional need to } \\
\text { maintain oxygen }\end{array}$ & 0 & 0 & 0 & 0 & \\
\hline
\end{tabular}

\section{Discussion}

This study aimed to compare the efficacy of breastfeeding, oral 25\% dextrose, KMCM, and EMLA cream in pain management following heal-prick sampling in term newborns, and the results showed that breastfeeding was the best method for pain management. After breastfeeding, dextrose, KMCM, and EMLA cream showed the least amount of pain, respectively. Blood sampling is the most leading cause of pain in hospitalized newborns. Premature infants or the ones being worked up for certain illnesses will be subjected to heel-prick or venous blood sampling between one to twenty-one times during their hospitalization (30). Considering the negative outcomes of pain sensation in infancy, it is mandatory to study, research, and palliate the pain experienced during these procedures (3). As our results showed, breastfeeding seems to be the optimal method for pain management in infants (31). This method contains pleasant factors, such as a bond with the mother (32), skin contact, sucking, and the sweet taste of milk (33), which, by itself, induces endorphins $(34,35)$. However, in addition, it is important to identify the actual factors involved in decreasing the perceived pain by the infant through breastfeeding. It was obvious that it was more than just the sweet taste of milk (36); it is likely that the fats and proteins of breast milk have a role in lowering pain perception by stimulating opioid receptors and nerve blocking (34). Moreover, it is said that breast milk and its fat content stimulate the release of the gut hormone cholecystokinin, which may lower the sensitivity to pain (37). Skin-to-skin contact between mother and infant, known as kangaroo mother care, is yet another method that has been found to be effective in reducing the perception of pain, but the mechanism of this action is unknown $(38,39)$. In this method, the infant is completely undressed (except for a diaper and a head-cover) and is leaned on the mother's breast and abdomen (9). Theoretically, sugar solutions increase the effectiveness of endorphins and act by stimulating the opioid receptors, which leads to the reduction of pain $(13,40)$. Emine et al. found that there was no significant difference between sucrose solution and breast milk, with both having significantly lower levels of perceived pain when compared to the control group (41). This study's findings were similar. Eghbalian et al. conducted a study comparing breast milk, glucose, and acetaminophen, and the results indicated that breast milk was the most efficacious (42). Although the glucose solution specimen in their study had a $50 \%$ concentration, we used a $25 \%$ concentration solution, which might be the reason for the lack of significant difference between the breast milk and the sugar water groups. Bilgen et al. studied the differences among $25 \%$ concentration solution of sucrose, breastfeeding and breast milk, which indicated that a $25 \%$ concentration solution of sucrose had the most palliative 
effect (22). Eriksson et al. conducted their study by comparing $25 \%$ concentration solution of glucose with $10 \%$ concentration of the same solution, which showed the higher efficiency of $25 \%$ concentration solution of glucose compared to the same solution of $10 \%$ concentration in lowering experienced pain and also crying time of the infant $(43,44)$. However, administering higher concentrations of sugar solutions to achieve pain palliation should be evaluated for possible side effects. With the aim of investigating the best type of sugar solutions in pain management, Blass et al. conducted a study that showed that sucrose was the best type of pain management, followed by fructose and glucose; however, lactose generated no pain relief at all (40). Therefore, it can be stated that pain-reducing properties of breast milk rely on factors other than lactose.

In a study conducted by Gradin et al., it was reported that the effect of a sugar solution (sucrose) in lowering pain perception was superlative to EMLA cream (45). A similar finding was reported in the study conducted by Abad et al. (46) \& Mucigant et al. (47). Also, Noori et al. reported the superiority of $30 \%$ concentration glucose solution in lowering pain perception in comparison with EMLA cream (48). Besides, the results of our study showed that sugar solution (25\% dextrose) provided better effectiveness than EMLA cream, as well. Although, according to the available studies and our study, it can be stated that breastfeeding and KMCM are the best ways for pain management in the infants who are undergoing painful procedures. However, more detailed studies should be conducted to achieve the best time for the intervention. The optimal concentration of sugar solution (while avoiding any possible side effects) and the optimal time between the intervention and the painful procedure are important to determine. It is also suggested that more trials be done regarding the pain-relieving properties of breast milk and breastfeeding. One of the limitations of this study was the absence of a control group. Even though each of the interventions used in this study was compared to a control group in previous studies, having a control group would have resulted in a more specific outcome in our study. Other limitations were the way the data were measured with the NIPS questioner, which was based on visual assessments, and, despite its use in other several studies, it is still a qualitative system and may cause distortion in the scoring system.

\section{Conclusions}

It seems that among the four methods of intervention in this study, the most effective method of lowering perceived pain in infants undergoing painful procedures was proven to be breastfeeding. This method resulted in a statistically significant lower average pain score when compared to groups being intervened with EMLA local anesthetic cream and skin contact (Kangaroo Mother Care). Further studies should be conducted to determine the differences between breastfeeding and the use of sugar solutions, such as dextrose, in pain management.

\section{Acknowledgments:}

The authors express their sincere thanks to the International Branch of the Shiraz University of Medical Sciences for the financial support that was provided for this study.

\section{Trial Registration:}

This study is registered in the Iranian Registry of Clinical Trials with the registration number of IRCT20151201253256N1.

\section{Funding:}

This research was supported financially by the Research Council of the International Campus of Shiraz University of Medical Sciences.

\section{Conflict of Interest:}

There is no conflict of interest to be declared.

\section{Authors' contributions:}

All authors contributed to this project and article equally. All authors read and approved the final manuscript.

\section{References:}

1) Bonica J. The need of a taxonomy. Pain. 1979; 6(3): 247. doi: 10.1016/0304-3959(79)90046-0.

2) Dilen B, Elseviers M. Oral glucose solution as pain relief in newborns: results of a clinical trial. Birth. 2010; 37(2): 98-105. doi: 10.1111/j.1523-536X.2010.00389.x, PMID: 20557532.

3) Whitfield MF, Grunau RE. Behavior, pain perception, and the extremely low-birth weight survivor. Clin Perinatol. 2000; 27(2): 363-79. doi: 10.1016/S0095-5108(05)70026-9, PMID: 10863655. 
4) Stevens B, Gibbins S, Franck LS. Treatment of pain in the neonatal intensive care unit. Pediatr Clin North Am . 2000; 47(3): 633-50. doi: 10.1016/S0031-3955(05)70230-3, PMID: 10835995.

5) Fulbrook P, Latour J, Albarran J, De Graaf W, Lynch F, Devictor D, et al. The presence of family members during cardiopulmonary resuscitation. Eur J Cardiovasc Nurs. 2007; 6(4):255-8. doi: 10.1016/j.ejcnurse.2007.07.003, PMID: 17919981.

6) Pasero C. Circumcision Requires Anesthesia and Analgesia: Need proof? Am J Nurs. 2001; 101(9): 22-3. doi: 10.1097/00000446-200109000-00014.

7) Lawrence J, Alcock D, McGrath P, Kay J, MacMurray SB, Dulberg C. The development of a tool to assess neonatal pain. Neonatal Netw. 1993; 12(6): 59-66. PMID: 8413140.

8) Gale G, VandenBerg K. Kangaroo care. Neonatal Netw. 1998; 17(5): 69-71. PMID: 9791453

9) Roller CG, Meyer K, Anderson GC. Birth kangaroo (skin-to-skin) care and breastfeeding: an eclamptic woman's story. MCN Am J Matern Child Nurs . 1999; 24(6): 294-5. doi: 10.1097/00005721-19991100000006, PMID: 10565143.

10) Bauer J, Sontheimer D, Fischer C, Linderkamp O. Metabolic rate and energy balance in very low birth weight infants during kangaroo holding by their mothers and fathers. J Pediatr. 1996; 129(4): 608-11. doi: 10.1016/S0022-3476(96)70129-4, PMID: 8859271.

11) Gómez PA, Baiges NM, Batiste FM, Marca GM, Nieto JA, Closa MR. [Kangaroo method in delivery room for full-term babies]. An Esp Pediatr. 1998; 48(6): 631-3. PMID: 9662849.

12) Gray L, Watt L, Blass EM. Skin-to-skin contact is analgesic in healthy newborns. Pediatrics. 2000; 105(1):e14-e. PMID: 10617751.

13) Grazel R. Neonatal pain management with oral sucrose. Worldviews on Evidence - based Nursing presents the archives of Online Journal of Knowledge Synthesis for Nursing. 2002; 9(1): 142-8. doi: 10.1111/j.1524-475x.2002.00142.x.

14) Taddio A, Shah V, Hancock R, Smith RW, Stephens D, Atenafu E, et al. Effectiveness of sucrose analgesia in newborns undergoing painful medical procedures. CMAJ. 2008; 179(1): 37-43. doi: 10.1503/cmaj.071734, PMID: 18591525, PMCID: PMC2464480.

15) Tarhani F, Momennasab M, Tarhani S. A Survey: Glucose Sedative Effect in Neonates during Venus Blood Sampling. Yafte journal of medical scienes. 2004; 6(2): 47-51.

16) McCullough S, Halton $T$, Mowbray D, Macfarlane PI. Lingual sucrose reduces the pain response to nasogastric tube insertion: a randomised clinical trial. Arch Dis Child Fetal Neonatal Ed. 2008; 93(2): F100-3. doi: 10.1136/adc.2006.110338, PMID: 17634178.

17) Cordoni A, Cordoni LE. Eutectic mixture of local anesthetics reduces pain during intravenous catheter insertion in the pediatric patient. Clin J Pain. 2001; 17(2): 115-8. doi: 10.1097/00002508-20010600000003, PMID: 11444712.

18) Tansky C, Lindberg CE. Breastfeeding as a pain intervention when immunizing infants. J Nurse Pract. 2010; 6(4): 287-95. doi: 10.1016/j.nurpra.2009.09.014.

19) Shahali S, Taavoni S, Haghani H, Neysani SE. Comparison of the Effect of Breast Sucking with Being in the Mother's Hug on Pain Relieving during Immunization Injection. Journal Of Babol University Of Medical Sciences. 2010; 11(5): 32-7.

20) Shah PS, Aliwalas L, Shah V. Breastfeeding or breastmilk to alleviate procedural pain in neonates: a systematic review. Breastfeed Med. 2007; 2(2): 74-82. doi: 10.1089/bfm.2006.0031, PMID: 17661578.

21) Malekan Rad E, Momtazmanesh N, Barkatin R. The effects of glucose, breast milk and lidocaine cream on acute pain of arteriopuncture in term neonates. KAUMS Journal (FEYZ). 2004; 8(2): 15-9.

22) Bilgen H, Özek E, Cebeci D, Örs R. Comparison of sucrose, expressed breast milk, and breast-feeding on the neonatal response to heel prick. J Pain. 2001; 2(5): 301-5. doi: 10.1054/jpai.2001.23140, PMID: 14622809.

23) Rogers TL, Ostrow CL. The use of EMLA cream to decrease venipuncture pain in children. J Pediatr Nurs . 2004; 19(1): 33-9. doi: 10.1016/j.pedn.2003.09.005, PMID: 14963868.

24) Buckley MM, Benfield P. Eutectic lidocaine/prilocaine cream A review of the topical anaesthetic/analgesic efficacy of a eutectic mixture of local anaesthetics (EMLA). Drugs. 1993; 46(1): 126-51. doi: 10.2165/00003495-199346010-00008, PMID: 7691503.

25) Taddio A, Shennan AT, Stevens B, Leeder JS, Koren G. Safety of lidocaine-prilocaine cream in the treatment of preterm neonates. J Pediatr. 1995; 127(6): 1002-5. doi: 10.1016/S0022-3476(95)70050-1, PMID: 8523173. 
26) Gourrier E, Karoubi P, El Hanache A, Merbouche S, Mouchnino G, Leraillez J. Use of EMLA cream in a department of neonatology. Pain. 1996; 68(2): 431-4. doi: 10.1016/S0304-3959(96)03208-3, PMID: 9121833.

27) Larsson B, Tannfeldt G, Lagercrantz H, Olsson G. Alleviation of the pain of venepuncture in neonates. Acta Paediatr. 1998; 87(7): 774-9. doi: 10.1111/j.1651-2227.1998.tb01746.x, PMID: 9722252.

28) Suraseranivongse S, Kaosaard R, Intakong P, Pornsiriprasert S, Karnchana Y, Kaopinpruck J, et al. A comparison of postoperative pain scales in neonates. $\mathrm{Br} \mathrm{J}$ Anaesth. 2006; 97(4): 540-4. doi: 10.1093/bja/ael184, PMID: 16885171.

29) Sarhangi F, Mollahadi M, Ebadi A, Matinzadeh ZK, Tadrisi SD. Validity and reliability of Neonatal Infant Pain Scale in Neonatal Intensive Care Units in Iran (2010). Pakistan Journal of Medical Sciences. 2011; 27(5).

30) Johnston CC, Collinge JM, Henderson SJ, Anand K. A cross-sectional survey of pain and pharmacological analgesia in Canadian neonatal intensive care units. Clin J Pain. 1997; 13(4): 308-12. doi: 10.1097/00002508-199712000-00008, PMID: 9430811.

31) Kapellou O. Blood sampling in infants (reducing pain and morbidity). Clinical evidence. $2011 ; 2011$.

32) Shah PS, Aliwalas LL, Shah VS. Breastfeeding or breast milk for procedural pain in neonates. The Cochrane Library. 2006. doi: 10.1002/14651858.cd004950.pub2.

33) Blass EM, Shide DJ, Zaw-Mon C, Sorrentino J. Mother as shield: Differential effects of contact and nursing on pain responsivity in infant rats: Evidence for nonopioid mediation. Behav Neurosci. 1995; 109(2): 342. doi: 10.1037/0735-7044.109.2.342, PMID: 7619324.

34) Gray L, Miller LW, Philipp BL, Blass EM. Breastfeeding is analgesic in healthy newborns. Pediatrics. 2002; 109(4): 590-3. doi: 10.1542/peds.109.4.590, PMID: 11927701.

35) Blass EM, Blom J. $\beta$-Casomorphin causes hypoalgesia in 10-day-old rats: evidence for central mediation. Pediatr Res. 1996; 39(2): 199-203. doi: 10.1203/00006450-199602000-00002, PMID: 8825787.

36) Ren K, Blass E, Dubner R. Suckling and sucrose ingestion suppress persistent hyperalgesia and spinal Fos expression after forepaw inflammation in infant rats. Proc Natl Acad Sci. 1997; 94(4): 1471-5. doi: 10.1073/pnas.94.4.1471, PMCID: PMC19815.

37) Weller A, Blass EM. Behavioral evidence for cholecystokinin-opiate interactions in neonatal rats. Am J Physiol. 1988; 255(6): R901-7. PMID: 3202224.

38) Johnston CC, Stevens B, Pinelli J, Gibbins S, Filion F, Jack A, et al. Kangaroo care is effective in diminishing pain response in preterm neonates. Arch Pediatr Adolesc Med. 2003; 157(11): 1084-8. doi: 10.1001/archpedi.157.11.1084, PMID: 14609899.

39) Johnson AN. Kangaroo holding beyond the NICU. Pediatr nurs. 2005; 31(1): 53. PMID: 15794326.

40) Blass EM, Smith BA. Differential effects of sucrose, fructose, glucose, and lactose on crying in 1-to 3-dayold human infants: Qualitative and quantitative considerations. Developmental Psychology. 1992; 28(5): 804. doi: 10.1037/0012-1649.28.5.804.

41) Efe E, Savaser S. The effect of two different methods used duringperipheral venous blood collection on pain reduction in neonates. Agri. 2007; 19(2): 49-56. PMID: 17760245.

42) Eghbalian F, Shalchi Z. Comparing The Efficacy Of Oral Glucose 50\%, Acetaminophen And BreastFeeding On Reducing Neonatal Pain. Urmia Medical Journal. 2014; 25(7): 578-85.

43) Eriksson M, Gradin M, Schollin J. Oral glucose and venepuncture reduce blood sampling pain in newborns. Early Hum Dev. 1999; 55(3): 211-8. doi: 10.1016/S0378-3782(99)00018-3, PMID: 10463785.

44) Campos RG. Rocking and pacifiers: two comforting interventions for heelstick pain. Res Nurs Health. 1994; 17(5): 321-31. doi: 10.1002/nur.4770170503, PMID: 8090943.

45) Gradin M, Eriksson M, Holmqvist G, Holstein $\AA$, Schollin J. Pain reduction at venipuncture in newborns: oral glucose compared with local anesthetic cream. Pediatrics. 2002; 110(6): 1053-7. doi: 10.1542/peds.110.6.1053, PMID: 12456899.

46) Abad F, Diaz - Gomez N, Domenech E, Gonzalez D, Robayna M, Feria M. Oral sucrose compares favourably with lidocaine - prilocaine cream for pain relief during venepuncture in neonates. Acta Paediatr. 2001; 90(2): 160-5. doi: 10.1111/j.1651-2227.2001.tb00278.x, PMID: 11236045.

47) Mucignat V, Ducrocq S, Lebas F, Mochel F, Baudon J, Gold F. [Analgesic effects of Emla cream and saccharose solution for subcutaneous injections in preterm newborns: a prospective study of 265 injections]. Arch Pediatr. 2004; 11(8): 921-5. doi: 10.1016/j.arcped.2004.03.028, PMID: 15288082. 